\title{
Histological and Morphometric Analysis of Testes of Adult Quail (Coturnix coturnix japonica) of Bangladesh
}

\author{
Análisis Histológico y Morfométrico de Testiculos de Codorniz Adulta \\ (Coturnix coturnix japonica) de Bangladesh
}

Subrata Kumar Shil"; Md. Abul Quasem* \& Mohammad Lutfur Rahman*

\begin{abstract}
SHIL, S. K.; QUASEM, A. \& RAHMAN, M. L. Histological and morphometric analyses of testes of adult quail (Coturnix coturnix japonica) of Bangladesh. Int. J. Morphol., 33(1):100-104, 2015.

SUMMARY: A histological and morphometric study was conducted to evaluate the seasonal testicular variations in the adult Japanese quail (Coturnix coturnix japonica) in Bangladesh. The weight of birds and testes, volume, length, circumference, seminiferous tubule diameter, circumference and height of germinal epithelium of testes were measured. Sections of testes obtained from studied birds were stained with $\mathrm{H} \& \mathrm{E}$ and images were taken by $\mathrm{J}$ software. Weight and volume of paired testes of quails significantly heavier $(\mathrm{P}<0.05)$ in long day period of summer and rainy season (March - September) than the short day period of autumn and winter (October February). Seasons had no significant effect on live weight gain of quails. The weight and diameter of testes or height of the germinal epithelium of the seminiferous tubule were positively correlated $(\mathrm{r}=0.84 ; \mathrm{r}=0.88)$. Spermatogenic activity was pronounced during summer and rainy season than that of autumn and winter $(\mathrm{P}<0.05)$.
\end{abstract}

KEY WORDS: Japanese quail; Morphometry; Testis; Season; Day length; Temperature.

\section{INTRODUCTION}

Reproduction of birds depends on photoperiod, rainfall, humidity, temperature and food as well as intrinsic factors (Lake, 1981; Lofts \& Murton, 1968). In temperate zones, seasonal day length variation serves as the primary role of timing reproductive periodicity (Lofts \& Murton). The majority of species outside the tropics rely on a food resource for their young that become available for a predictable period each year. The length of the breeding season varies between species, but in the vast majority, the breeding season is asymmetrical with changes in photoperiod. When mature male coturnix were exposed to short photoperiods (6L: 18D) a rapid testicular weight reduction was recorded (Follett \& Farner, 1966). Reduction of testicular weight in the common coturnix, exposed to short days ( $8 \mathrm{~h}$ of light), was more rapid in a colder than in a warmer environment (Wilson et al., 1971). The two most critical features in the seasonality of an environment are the amplitude of the seasonal fluctuations and the precision with which these fluctuations occur each year (Wingfield et al., 1992). The physiological processes that underlie the timing of breeding in birds have been studied extensively in temperate zone species (Wingfield et al., 1992; Ball, 1993; Cockrem, 1995; Hahn et al., 1997). Bangladesh has a subtropical monsoon climate characterized by wide seasonal variations in rainfall, moderately warm temperatures, and high humidity and there is a little research work to assess the effect of different factors on morphometry of testis. Therefore, this study was conducted to evaluate the effect of season and daylights on morphometry of testis of quail in Bangladesh.

\section{MATERIAL AND METHOD}

Collection of birds. The study was performed on 120 sexually matured domestic quails (Coturnix coturnix japonica) weighing average $119.15 \pm 7.46 \mathrm{~g}$ (range $110 \mathrm{~g}$ to $130 \mathrm{~g}$ ). The quail was routinely collected from a recognized farm of Chittagong Metropolitan area, Bangladesh during different seasons of the year. Forty quails were collected during summer (March-June), 30

\footnotetext{
" Department of Anatomy and Histology, Faculty of Veterinary Medicine, Chittagong Veterinary \& Animal Sciences University, Zakir Hossain Road, Khulshi, Bangladesh.
} 
during rainy (July- September), 20 during autumn (October-November) and 30 during winter (DecemberFebruary). The birds were euthanized ( $30 \mathrm{mg} / \mathrm{kg}$ bw/im) and the testes were collected from each individual bird.

Gross morphometry. After separation of testis, specimen was subjected to gross anatomical measurement. Volume of testes was measured by Archimedes' principle of water displacement using normal saline $(0.85 \% \mathrm{NaCl})$ and results were recorded in cubic milliliters (Bath \& Chaudhari, 2002). Length of testes was measured by vernier digital calipers (0-150 digital caliper, Shinko Denshi Co. Ltd, Japan). Relative testis weight was measured according to formula as follows: (weight of paired testes / body weight) $¥ 100$ (Orlu \& Egbunike, 2010).

Tissue processing. Sampled testes were immediately immersed in Bouin's fixative and submitted to prefixation for approximately 20 minutes. Longitudinal sections of testes were then made and sections were immersed in histological fixatives for $24 \mathrm{~h}$ in order to complete fixation. Small testis fragments were used for the routine histology such as dehydration, clarification and paraplast embedding and stained with hematoxylin-eosin (HE).

Histomorphometry. A total of 12 testes from quails were collected during summer, 9 during rainy, 6 during autumn and 9 during winter season were used for thorough histological study. In order to record histomorphometric data 10 photomicrographs were taken randomly from the central zone of cross-sections of each testis using a Photomicroscope (AmScope Trinocular compound microscope +1.3 MP camera, Model T490 B-MT) and Toup View 3.0 image processing software. Using ImageJ 1.45 image measurement software, diameters were calculated from 20 randomly selected cross-sections of the seminiferous tubules in each testis and recorded their average values. Temperature and day length were recorded from the official website (www.bmd.gov.bd) of Bangladesh Meteorological Department of Government of the People's Republic of Bangladesh.

Data analysis. Student paired t-tests were used to compare between paired groups, whereas the one way analysis of variance (ANOVA) was used to compare the differences in weight, volume, circumference and length of testes, seminiferous tubule diameter, height of germinal epithelium across the groups. SPSS statistical software (Ver.16.0 for windows, SPSS) was used for analysis of the data. Results were expressed as arithmetic Mean \pm Standard Deviation (Mean \pm SD). The differences were considered to be significant if $\mathrm{P}$ was $\leq 0.05$.

\section{RESULTS}

Morphometry of testes of quail by season and length of day light. Mean live weight of the Japanese quail $(n=120)$ was $119.15 \pm 7.46 \mathrm{~g}$. Average paired testicular weight, volume, length and circumference were significantly higher in summer and rainy seasons than in autumn and winter $(\mathrm{P}=0.02)$. The average weight of testes was significantly heavier $(3.17 \pm 0.66$ g) during long day period (summer and rainy season) than that of short day period $(1.27 \pm 0.28 \mathrm{~g})(\mathrm{P}=0.03)$ (Fig. 1). Regardless of seasons positive correlation was recorded between the day length and paired testicular weight ( $\mathrm{r}=0.82)$. However, paired testes weight were about 2.5 fold higher in summer than in winter. Relative testes weight was higher in summer $(2.75 \pm 0.50 \%)$ and rainy season $(2.45 \pm 0.44 \%)$ than the autumn $(1.05 \pm 0.22 \%)$ and winter $(1.13 \pm 0.29 \%)$.

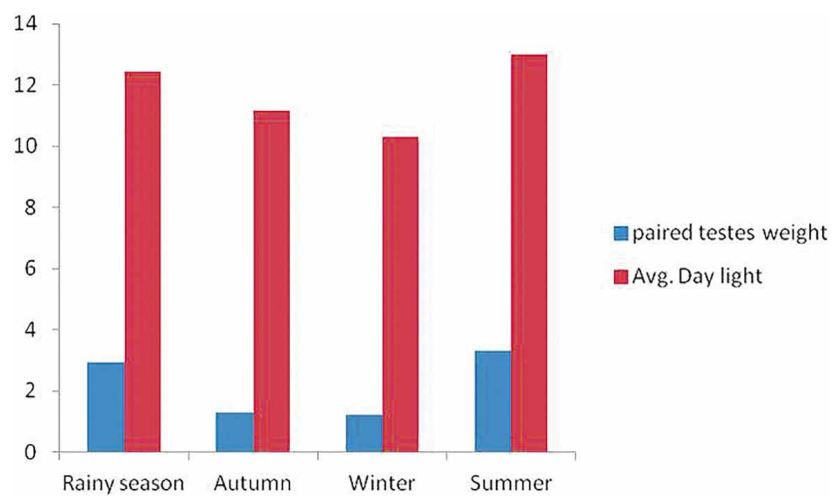

Fig. 1. Paired testes weight in relation to natural photoperiod in different seasons.

Morphometry of seminiferous tubule by season and day length. Morphometric evaluation of seminiferous tubules revealed that in summer and rainy season they had their higher diameter, circumference and germinal epithelium height than in autumn and winter (Figs. 2, 3, 4, 5, 6). Thus seminiferous tubules revealed a seasonal variation with two phases: (1) reproductive active phase, (2) regressive phase. Elevated values were observed in long day period (May - July) and decreased progressively until December. A new increase occurred in February, March, followed by an increase in April, May, June and in July it reaches its peak and a progressive decrease until December. The variation of the height of the seminiferous epithelium in general accompanied the annual variation of the tubular diameter. Moderate peaks were observed in autumn (October, November) and maximum values in summer and rainy season i.e. from March to September (a marked peak). The lowest values were detected in winter season (November, December and January). There was strong positive correlation $(r=0.84)$ between seminiferous tubule diameter and paired testes weight throughout the year. Increase in testes weight also correlated 
well with the increase of height $(\mathrm{r}=0.88)$ of the germinal epithelium of the seminiferous tubule.

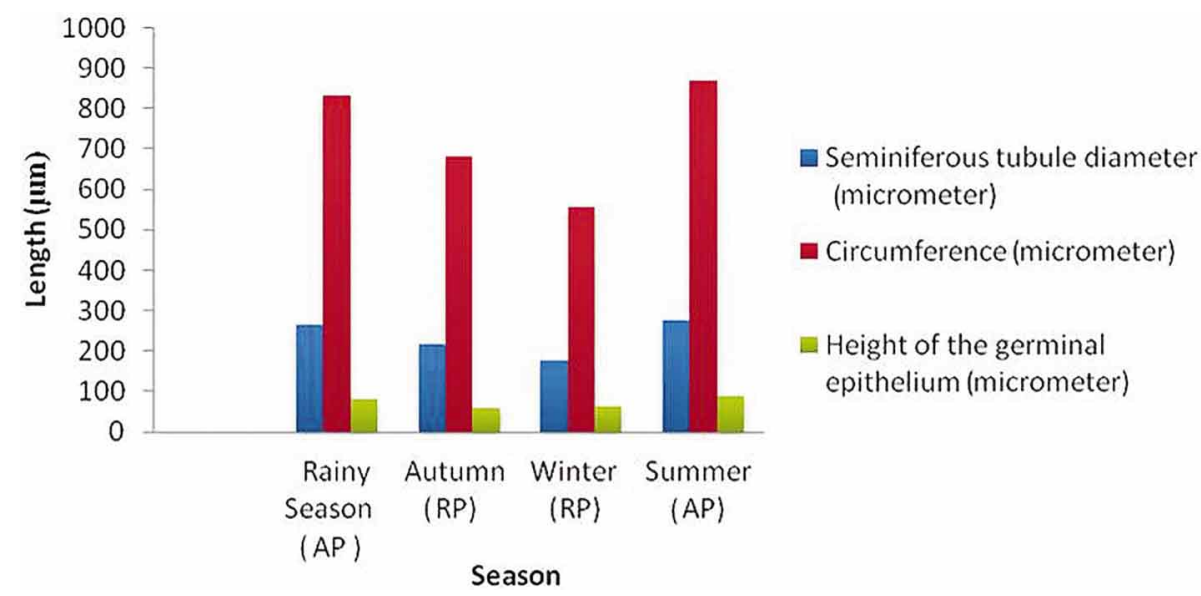

Fig. 2. Seasonal variation in histomorphometry of seminiferous tubule.

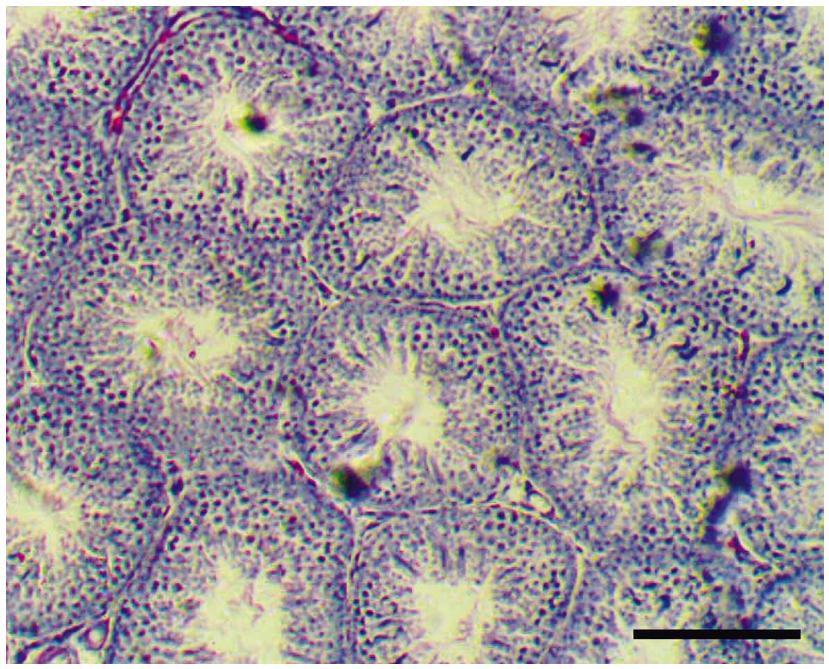

Fig. 3. Histological characters of seminiferous tubule in Summer (June) (scale bar $200 \mu \mathrm{m}$ ).

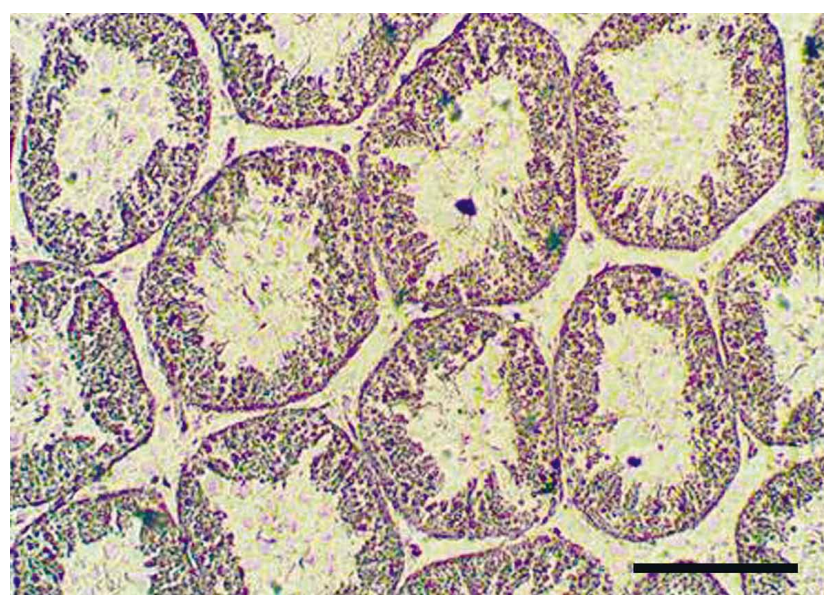

Fig. 5. Histological characters of seminiferous tubule in Autumn (October) (scale bar $200 \mathrm{~mm}$ )

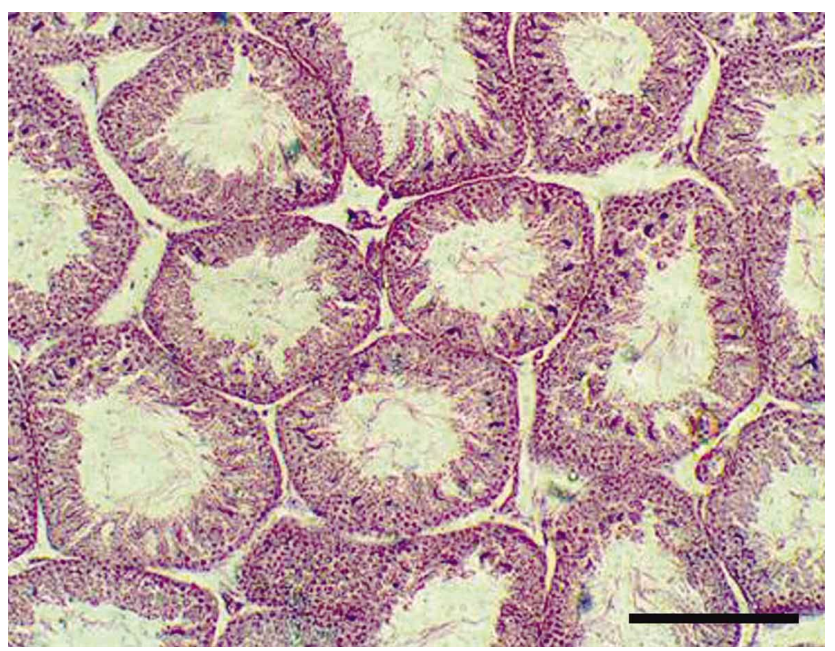

Fig. 4. Histological characters of seminiferous tubule in Rainy season (August) (scale bar $200 \mu \mathrm{m}$ ).

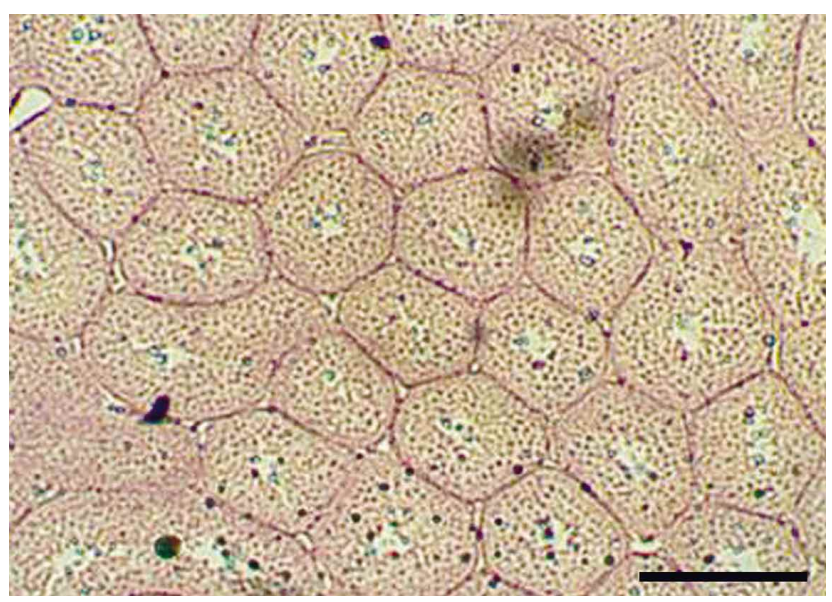

Fig. 6. Histological characters of seminiferous tubule in Winter (January) (scale bar $200 \mathrm{~mm}$ ). 


\section{DISCUSSION}

Gross Morphometry. Our study reveals that testes weight of quail varied significantly with the season. These results partially agree with some previous findings (Haldar \& Rai, 1997; Haldar \& Singh, 2001; Akbar et al., 2012) but the exception is the inactive phase in winter. This observation confirmed the results of Akbar et al. in Japanese quails of Pakistan who reported the higher paired testicular weight $(4.53 \pm 0.370 \mathrm{~g})$ in summer (sexually active phase) and lowest $(0.78 \pm 0.048 \mathrm{~g})$ in winter (inactive phase). In this study paired testes weight of quail was found more than $1.0 \mathrm{~g}$. Spermatogenic activity is closely related to testes weight and in young quail it had to exceed $1.0 \mathrm{~g}$ for full spermatogenic activity (Wilson, 1972). Higher relative paired testes weigh in summer season indicates their reproductive active phase and lower in autumn and winter indicates their regressive phase.

Histomorphometry. In the present study, the spermatogenic activity of the domestic quail was evaluated on the basis of the diameter of seminiferous tubules and germinal epithelium height. We found that seminiferous tubule diameter, height of the germinal epithelium and circumference of the cross section of the seminiferous tubule were significantly $(\mathrm{P}<0.05)$ higher in summer and rainy season (March to September) as compared with autumn and winter (October to February). Though the height of the germinal epithelium were lower in autumn and winter (57.5 $2.5 \mu \mathrm{m}$ and $61.0 \pm 8.54 \mu \mathrm{m}$ respectively), mature spermatozoa were found in the lumen of seminiferous tubule throughout the year. Study on quail in Brazil of southern hemisphere of the world, Baraldi-Artoni et al. (2007) observed the moderate peaks values of seminiferous tubule diameter in January, April and May and maximum values in September (a marked peak). The lowest values were detected in March, August and December. Highest and lowest values were 155 $\mu \mathrm{m}$ and $75 \mu \mathrm{m}$ respectively which differ with findings of present study. In our findings, mature spermatozoa in the lumen indicate that their reproductive efficiency throughout the year but have two phases in its annual reproductive cycle: sexually active phase stays throughout the period of summer and rainy season and regressed phase in autumn and winter. These results agreed with previous findings (Haldar \& Rai; Haldar \& Singh) but differ in some points. They have found in this tropical environment (India) that the Indian jungle bush quail (Perdicula asiatica) had three distinct phases reproductive active phase in summer, regressive phase in autumn and nonactive phase in winter. In Bangladesh, winter does not show an extreme weather in terms of temperature and day length, so this may be the cause for not finding the sexually inactive phase of testis in winter (December - February). Akbar et al. found that Japanese quails in Pakistan showed reproductive active phase (June - July), regressive phase (September October) and non-active phase (January - February). BaraldiArtoni et al. have found four distinct phases in annual cycle of Japanese quail in Brazil: a resting phase (at the end of summer), a recrudescence phase (in the fall), a proliferative phase (at the end of winter and beginning of spring) and a regression phase (spring and summer).

Effect of day length. In summer (March - June) and rainy season (July - September) day length ranges from 12 hours to 13 and half hours. But in autumn (October - November) and winter (December - February) it ranges from 10 and half to 12 hours in Bangladesh. Baraldi-Artoni et al. also found elevated and maximum spermatogenic activity in fall-winter (shortday period) and at the beginning of spring, respectively and lower activity during spring and summer (long-day periods) with minimum values at the end of summer. Boon et al. (2000) and Mills et al. (1997) found that in Japanese quail sexual development is depend on the length of the daily light period: long photoperiods stimulate sexual maturation, while short photoperiods inhibit or delay sexual maturation. They found increased testicular weight and volume in long day period but in contrast, growth under or transfer of sexually developed birds to short days was found regression of gonadal development and function. Light shift experiments have also demonstrated that transfer of such sexually regressed males back to long day results in re growth and restored function of the testes (Domjan, 1987; Chaturvedi et al., 1992). Oishi \& Konishi (1983), Delville et al. (1984) and Domjan they have also found the fully developed gonad of quail in long day period.

\section{CONCLUSION}

It is suggested that the degree of gonadal growth in quail depends on the availability of daily photoperiod. Artificial illumination in short day period (autumn and winter) may keep quail sexually active throughout the year.

\section{ACKNOWLEDGEMENTS}

Authors are grateful to Danish International Developing Agency (DANIDA) funded Poultry Research and Training Center (PRTC) for financial support. Authors also express their highest gratitude to Prof. Dr. Md. Ahasanul Haque for his valuable suggestions. 
SHIL, S. K.; QUASEM, A. \& RAHMAN, M. L. Análisis histológico y morfométrico de testiculos de codorniz adulta (Coturnix coturnix japonica) de Bangladesh. Int. J. Morphol., 33(1):100-104, 2015.

RESUMEN: Se realizó un estudio histológico y morfométrico para evaluar las variaciones testiculares estacionales de la codorniz japonesa adulta (Coturnix coturnix japonica) en Bangladesh. Se midieron el peso de las aves y sus testículos; el volumen, longitud, circunferencia y diámetro de los túbulos seminíferos, y la circunferencia y altura del epitelio germinal testicular. Secciones de testículos obtenidos de las aves estudiadas fueron teñidas con H\&E y las imágenes fueron analizadas con el programa ImageJ. Se registró un aumento significativo en peso y volumen de los testículos de codornices $(\mathrm{P}<0,05)$ en el periodo día de verano y en la temporada de lluvia (marzo-septiembre) al período del día corto de otoño e invierno (octubre-febrero). El período estacionario no tuvo efecto significativo sobre el aumento de peso vivo de las codornices. El peso y el diámetro de los testículos, y la altura del epitelio germinal del túbulo seminífero se correlacionaron positivamente ( $\mathrm{r}=0,84 ; \mathrm{r}=0,88)$. La actividad espermatogénica fue más pronunciada durante el verano y durante la temporada de lluvias que en otoño e invierno ( $\mathrm{p}<0,05)$.

PALABRAS CLAVE: Codorniz japonesa; Morfometría; Testículo; Estación; Duración del día; Temperatura.

\section{REFERENCES}

Akbar, Z.; Qureshi, A. S. \& Rahman. S. U. Effects of seasonal variation in different reproductive phases on the cellular response of bursa and testes in Japanese quails (Coturnix japonica). Pak. Vet. J., 32(4):525-9, 2012.

Ball, G. F. The neural integration of environmental information by seasonally breeding birds. Am. Zool., 33:185-99, 1993.

Baraldi-Artoni, S. M.; Bottino, F.; Oliveira, D.; Sobue Franzo, V.; Amoroso, L.; Orsi, A. M. \& Cruz, C. Morphometric study of Rynchotus rufescens testis throughout the year. Braz. J. Biol., 67(2):363-7, 2007.

Bath, G. S. \& Chaudhari, S. U. R. Sperm reserves and its relationship to parameters of the testis, epididymis and vas deferens of local cocks in the Sahel Region of Nigeria. Int. J. Agric. Biol., 4(4):561-4, 2002.

Boon, P.; Visser, G. H. \& Daan, S. Effect of photoperiod on body weight gain, and daily energy intake and energy expenditure in Japanese quail (Coturnix c. japonica). Physiol. Behav., 70(3-4):249-60, 2000.

Chaturvedi, C. M.; Dubey, L. \& Phillips, D. Influence of different photoperiods on development of gonad, cloacal gland and circulating thyroid hormones in male Japanese quail Coturnix coturnix japonica. Indian J. Exp. Biol., 30(8):680-4, 1992.

Cockrem, J. F. Timing of seasonal breeding in birds, with particular reference to New Zealand birds. Reprod. Fert. Dev., 7(1):1-19, 1995.

Delville, Y.; Hendrick, J. C.; Sulon, J. \& Balthazart, J. Testosterone metabolism and testosterone-dependent characteristics in Japanese quail. Physiol. Behav., 33(5):817-23, 1984.

Domjan, M. Photoperiodic and endocrine control of social proximity behavior in male Japanese quail (Coturnix coturnix japonica). Behav. Neurosci., 101(3):385-92, 1987.

Follett, B. K. \& Farner, D. S. Pituitary gonadotropins in the Japanese quail (Coturnix coturnix japonica) during photoperiodically induced gonadal growth. Gen. Comp. Endocrinol., 7:125-31, 1966.

Hahn, T. P.; Boswell, T.; Wingfield, J. C. \& Ball, G. F. Temporal flexibility in avian reproduction. In: Nolan, V. Jr.; Ketterson, E. D. \& Thompson, C. F. (Eds.). Current Ornithology. New York, Plenum, 1997. pp.9-80.

Haldar, C. \& Rai, V. Photoperiod, indoleamines, and ovarian responses in the Indian tropical jungle bush quail Perdicula asiatica. J. Exp. Zool., 277(6):442-9, 1997.
Haldar, C. \& Singh, S. S. Melatonin and immunological functions/expression by the bursa of Fabricius in Indian jungle bush quail (Perdicula asiatica). Avian Endocrinol., 1:427-35, 2001.

Lake, P. E. Male genital organs. In: Kim, A. S. \& McLelland, J. (Eds.). Form and function in birds. London, Academic Press, 1981. pp. 1-61.

Lofts, B. \& Murton, R. K. Photoperiodic and physiological adaptations regulating avian breeding cycles and their ecological significance. $J$. Zool., Lond., 155(3):327-94, 1968.

Mills, A. D.; Crawford, L. L.; Domjan, M. \& Faure, J. M. The behavior of the Japanese or domestic quail Coturnix japonica. Neurosci. Biobehav. Rev., 21(3):261-81, 1997.

Oishi, T. \& Konishi, T. Variations in the photoperiodic cloacal response of Japanese quail: association with testes weight and feather color. Gen. Comp. Endocrinol., 50(1):1-10, 1983.

Orlu, E. E. \& Egbunike, G. N. Breed and seasonal variations in the testicular morphometry, gonadal and extragonadal sperm reserves of the barred plymouth rock and Nigerian indigenous breeds of the domestic fowl. Pak. J. Biol. Sci., 13(3):120-5, 2010.

Wilson, W. O. A review of the physiology of coturnix (Japanese quail). World Poult. Sci. J., 28(4):413-429, 1972.

Wilson, W. O.; Cain, J. R. \& Siopes, T. D. The interaction of light and temperature in Coturnix. Poult. Sci., 50(1):204-7, 1971.

Wingfield, J. C.; Hahn, T. P.; Levin, R. \& Honey, P. Environmental predictability and control of gonadal cycles in birds. J. Exp. Zool., 261:214-31, 1992.

Correspondence to:

Subrata Kumar Shil, DVM, MS

Assistant Professor

Department of Anatomy and Histology

Chittagong Veterinary and Animal Sciences University

Khulshi-4202

Chittagong - BANGLADESH

Email: skshilvet@yahoo.com

Received: 19-05-2014

Accepted: 05-11-2014 